Jurnal

Kardiologi Indonesia

J Kardiol Indones. 2015;36:94-II 0

ISSN $0126 / 3773$

\title{
Atrial Fibrillation in Chronic Obtruktive Pulmonary \\ Disease
}

\author{
Silmi Kaffah', Yoga Yuniadi², Erlang Samoedro'.
}

'Departemen Pulmonologi Dan Ilmu Kedokteran Respirasi Fakultas Kedokteran Universitas Indonesia Departemen Kardiologi Dan Kedokteran Vaskular Fakultas Kedokteran Universitas Indonesia Jakarta
Chronic Obstructive Pulmonary Disease (COPD) often coexists with cardiovasculae disease (comorbidities) that may have a significant impact in prognosis. Atrial fibrillation (AF) is the most common comorbid, which is supraventricular tachyarrhythmias uncoordinated and ineffective atrial activation. Emergence of atrial fibrillation if not handled properly associated with morbidity and mortality are high . Exact pathogenesis of AF in COPD but may associated with atrial factors, inflammation, activation of the renin - angiotensin - aldosterone system (RAAS), coronary heart disease , disorders of the autonomic tone and pharmacological. Complications of AF consisted of thromboembolic events including stroke. The management of AF with COPD should be adjusted to optimize therapeutic result

(J Kardiol Indones. 20I5;36:94-I I0)

Keywords: Atrial Fibrillation, Chronic Obstructive Pulmonary Disease, Pathophysiology, Complication, Management 


\title{
Fibrilasi Atrium pada Penyakit Paru Obtruktif Kronik
}

\author{
Silmi Kaffah', Yoga Yuniadi², Erlang Samoedro'.
}

\begin{abstract}
Penyakit Paru Obstruktif Kronik (PPOK) yang disertai penyakit kardiovaskular sebagai komorbid akan memperberat prognosis. Komorbid tersering adalah fibrilasi atrium yaitu takiaritmia supraventrikular yang tidak terkoordinasi dan tidak efektifnya aktivasi atrium. Munculnya fibrilasi atrium apabila tidak tertangani dengan baik berkaitan dengan angka morbiditas dan mortalitas yang tinggi. Patofisiologi fibrilasi atrium pada PPOK diduga antara lain akibat faktor atrium, inflamasi, aktivasi sistem renin-angiotensin-aldosteron, penyakit jantung koroner, gangguan tonus otonom dan farmakologis. Komplikasi fibrilasi atrium adalah terjadinya tromboemboli sistemik yaitu stroke. Penatalaksanaan fibrilasi atrium pada PPOK harus disesuaikan agar mencapai hasil pengobatan optimal.
\end{abstract}

(J Kardiol Indones. 2015;36:94-110)

Kata kunci: Penyakit Paru Obstruktif Kronik, Fibrilasi Atrium, Patofisiologi, Komplikasi, Tatalaksana

$\mathrm{P}$ enyakit Paru Obstruktif Kronik (PPOK) akan tetap menjadi masalah kesehatan di dunia dan merupakan penyebab kematian terbanyak ke empat di dunia. ${ }^{1}$ Berdasarkan data World Health Organization (WHO) tahun 2004, enam puluh empat juta orang menderita PPOK dan sebanyak tiga juta orang di dunia meninggal akibat

\footnotetext{
Alamat Korespondensi dr. Silmi Kaffah

'Departemen Pulmonologi Dan Ilmu Kedokteran Respirasi Fakultas Kedokteran Universitas Indonesia. ${ }^{2}$ Departemen Kardiologi Dan Kedokteran Vaskular Fakultas Kedokteran Universitas Indonesia Jakarta. E-mail: yogay136@gmail.com
}

PPOK setiap tahunnya. World Health Organization (WHO) juga memprediksi tahun 2030, PPOK akan menjadi penyebab ketiga kematian di dunia. ${ }^{2}$ Merokok merupakan faktor resiko utama terjadinya PPOK, namun merokok bukan satu-satunya faktor resiko PPOK. Faktor terjadinya PPOK selain rokok antara lain pajanan terhadap debu organik, anorganik, bahan kimia dan polusi udara yang dihasilkan dari pembakaran kayu atau bahan biomass lainnya. ${ }^{1}$

Definisi PPOK menurut GOLD 2015 adalah penyakit paru yang dapat dicegah dan diobati ditandai oleh hambatan aliran udara yang bersifat progresif dan berhubungan dengan respons inflamasi pada paru dan saluran pernapasan terhadap partikel dan gas berbahaya. Eksaserbasi dan penyakit komorbid 
berperan serta terhadap keparahan masing-masing pasien. ${ }^{3}$ Perhimpunan Dokter Paru Indonesia (PDPI) mendefinisikan PPOK adalah penyakit paru yang dapat dicegah dan diobati, ditandai oleh hambatan aliran udara yang tidak sepenuhnya reversibel, bersifat progresif dan berhubungan dengan respons inflamasi paru terhadap partikel atau gas yang beracun disertai efek ekstra paru yang berkontribusi terhadap derajat berat penyakit. ${ }^{4}$

Penyakit Paru Obstruktif Kronik (PPOK) sering disertai dengan penyakit lain (komorbid) yang akan memperberat prognosis. Penyakit kardiovaskular merupakan faktor komorbid utama pada PPOK. ${ }^{5}$ Hipertesi pulmoner pada PPOK dianggap sebagai akibat kondisi hipoksia vasokontriksi pulmoner, polisitemia dan kerusakan vaskular paru oleh emfisema. Hipertensi pulmoner merupakan mekanisme yang mendasari terjadinya hipertrofi ventrikel kanan dan kor pulmonal. Hipertensi pulmoner terjadi apabila tekanan arteri pulmoner rata-rata $>20 \mathrm{mmHg}$, akibat dari peningkatan resistensi vaskuler pulmoner, sehingga terjadi dilatasi dan hipertrofi ventrikel kanan (kor pulmonal). ${ }^{6}$

Fibrilasi atrium (FA) merupakan komplikasi kardiovaskular tersering pada PPOK. Kor pulmonal, asidosis, hipoksemia dan penyakit jantung iskemik (PJI) merupakan penyebab utama hubungan PPOK dengan arimia. Risiko aritmia pada pasien PPOK dipengaruhi oleh derajat PPOK, misalnya terjadi pada PPOK eksaserbasi dengan supraventikular takikardi. Pada PPOK stabil tidak menutup kemungkinan didapatkan insiden fibrilasi atrium yang cukup besar. $^{6}$

Penelitian prospektif oleh Buch dkk yang dilakukan di The Copenhagen City Heart Study (CCHS) menjelaskan bahwa penurunan persentase Volume Ekspirasi Paksa detik pertama prediksi (VEP $1 \%$ prediksi) adalah faktor independen mulainya onset baru FA, apabila tidak diobati dapat menyebabkan stroke dan angka kematian yang tinggi. Penelitian ini juga menekankan pentingnya elektrokardiografi (EKG) rutin pada pasien dengan PPOK. ${ }^{7}$ Sin dkk mendapatkan pada pasien PPOK mempunyai risiko tinggi terjadinya gagal jantung kongestif, aritmia dan infark miokard akut. Pasien rawat inap PPOK dengan gagal napas akut mepunyai tingkat kematian 70\% yang berkaitan dengan aritmia. Angka kematian PPOK dengan aritmia pada pasien rawat inap sebesr 31\% dan tanpa aritmia sebesar $8 \% .{ }^{8}$ Tinjauan pustaka ini akan membahas tentang fibrilasi atrium pada pasien PPOK.

\section{Diagnosis PPOK Berdasarkan Gold 2015}

Penegakan diagnosis PPOK harus mempertimbangkan beberapa aspek antara lain derajat berat gejala pasien, nilai spirometri, risiko eksaserbasi dan komorbiditas. Dalam mendiagnosis PPOK dapat dipikirkan apabila pasien dengan gejala sesak napas, batuk kronik, poduksi sputum dan mempunyai riwayat faktor risiko. Spirometri digunakan dalam penegakkan diagnosis apabila didapatkan Volume Ekspirasi Paksa detik pertama (VEP1) dan Kapasitas Volume Paksa (KVP) kurang dari 0,70. Sesak napas pada PPOK dapat dinilai dengan kuisioner seperti The Modified British Medical Researh Council (mMRC) dan COPD Assessment Test (CAT). The Modified British Medical Researh Council (mMRC) digunakan untuk menilai gejala yang berhubungan dengan status kesehatan dan memperkirakan risiko mortalitas. Cut of point $\mathrm{mMRC}$ adalah 2, nilai mMRC bernilai 0 sampai dengan 4 berupa pernyataan sesak. Tabel 1 menjabarkan isi kuisioner mMRC.,, 9 COPD Assessment Test (CAT) adalah suatu kuisioner yang singkat dan mudah untuk menilai pengaruh PPOK terhadap status kesehatan. Kuisioner CAT merupakan kuisioner yang terdiri dari 8 pernyataan tervalidasi dengan nilai 0 sampai 40. Nilai cut of point CAT kurang dari 10. Pasien PPOK dengan nilai CAT kurang dari 10 dimasukkan dalam kelompok A dan C. Kuisioner CAT dapat pula digunakan untuk menilai efektifitas pengobatan terutama dalam hal pencegahan dan penatalaksanaan PPOK eksaserbasi maupun untuk mengevaluasi progresifitas penyakit. Tabel 2 menjabarkan tentang isi kuisioner CAT. ${ }^{3,11}$

Tabel 1. Kuisioner The Modified British Medical Research Council (mMRC)

\begin{tabular}{ll}
\hline Derajat & Keluhan sesak napas \\
\hline 0 & Saya tidak sesak kecuali saat latihan berat \\
1 & Saya sesak saat berjalan bergegas atau saat mendaki bukit \\
& kecil \\
2 & $\begin{array}{l}\text { Pada permukaan yang datar, saya berjalan lebih lambat } \\
\text { dibandingkan teman sebaya }\end{array}$ \\
3 & $\begin{array}{l}\text { Saya harus berhenti untuk bernapas setelah berjalan } \\
\text { kira-kira } 100\end{array}$ \\
& $\begin{array}{l}\text { yard ( } 91,44 \text { meter) } \\
\text { Saya terlalu sesak untuk keluar rumah atau sesak saat } \\
\text { menggunakan } \\
\text { atau melepaskan pakaian. }\end{array}$
\end{tabular}

Dikutip dari (3) 
Kaffah S dkk: Fibrilasi atrium pada penyakit paru obtruktif kronik

Tabel 2. COPD Assessment Test (CAT)

\begin{tabular}{|c|c|c|c|c|c|c|c|}
\hline COPD Assessment Test (CAT) & & & & & & & \\
\hline Saya tidak pernah batuk & 0 & 1 & 2 & 3 & 4 & 5 & Saya selalu batuk \\
\hline Tidak ada dahak sama sekali & 0 & 1 & 2 & 3 & 4 & 5 & Dada saya penuh dengan dahak \\
\hline Tidak ada rasa berat (tertekan) di dada & 0 & 1 & 2 & 3 & 4 & 5 & Dada saya terasa berat (tertekan) sekali \\
\hline $\begin{array}{l}\text { Ketika saya jalan mendaki/naik tangga saya } \\
\text { tidak sesak }\end{array}$ & 0 & 1 & 2 & 3 & 4 & 5 & $\begin{array}{l}\text { Ketika saya jalan mendaki/naik tangga saya sangat } \\
\text { sesak }\end{array}$ \\
\hline Aktivitas sehari-hari saya di rumah tidak terbatas & 0 & 1 & 2 & 3 & 4 & 5 & Aktivitas sehari-hari di rumah sangat terbatas \\
\hline $\begin{array}{l}\text { Saya tidak khawatir keluar rumah meskipun menderita } \\
\text { penyakit paru }\end{array}$ & 0 & 1 & 2 & 3 & 4 & 5 & $\begin{array}{l}\text { Saya sangat khawatir keluar rumah meskipun saya } \\
\text { menderita penyakit paru }\end{array}$ \\
\hline Saya dapat tidur dengan nyenyak & 0 & 1 & 2 & 3 & 4 & 5 & Saya tidak dapat tidur dengan nyenyak \\
\hline Saya sangat bertenaga & 0 & 1 & 2 & 3 & 4 & 5 & Saya tidak punya tenaga sama sekali \\
\hline
\end{tabular}

Dikutip dari (11)

Klasifikasi spirometri berdasarkan GOLD 2015, nilai cut of points untuk diagnosis PPOK adalah VEP1/ KVP kurang dari 0,70 pasca bronkodilator (BD). Kelompok GOLD 1 memiliki nilai $\mathrm{VEP}_{1}$ lebih dari $80 \%$ prediksi, hambatan aliran udara ringan dan pasien tidak sadar jika mereka mempunyai kelainan fungsi paru. Kelompok GOLD 2 mempunyai nilai VEP 1 $50 \%$ sampai $80 \%$ dan pasien mulai berobat disebabkan keluhan respirasi kronik. Kelompok GOLD 3 memiliki nilai VEP $130 \%$ hingga 50\%. Kelompok GOLD 4 memiliki nilai VEP1 kurang dari 30\%. Tabel 3 menjelaskan pembagian kelompok PPOK berdasarkan VEP1. ${ }^{3}$ Risiko munculnya onset baru FA pada PPOK 1,8 kali lebih tinggi pada $\mathrm{VEP}_{1} \%$ prediksi 60-80\% dibandingkan dengan $\mathrm{VEP}_{1} \%$ prediksi $\geq$ $80 \%$. Risiko FA pada PPOK yang menjalani rawat inap 1,3 kali lebih tinggi pada VEP $1 \%$ prediksi $<60 \%$ dibandingkan dengan $\mathrm{VEP}_{1} \%$ prediksi $>80 \%{ }^{7}$

Eksaserbasi akut pada PPOK merupakan timbulnya perburukan dibandingkan dengan kondisi sebelumnya. Gejala eksaserbasi antara lain sesak bertambah, produksi sputum meningkat, dan perubahan warna sputum menjadi purulen. Eksaserbasi akut dibagi menjadi tiga yaitu tipe I (eksaserbasi berat) apabila memiliki tiga gejala diatas, tipe II (eksaserbasi sedang) memiliki dua gejala diatas, tipe III (eksaserbasi ringan) memiliki 1 gejala diatas ditambah infeksi saluran napas lebih dari 5 hari, demam tanpa sebab lain, peningkatan batuk, peningkatan mengi atau peningkatan frekuensi pernapasan $>20 \%$ nilai dasar. ${ }^{4}$ Pada PPOK stabil didapatkan 7\% fibrilasi atrium, $9 \%$ prolonged corrected QT (QTc), 2\% left bundle branch block (LBBB) dan $7 \%$ right bundle branch block, dan memiliki gambaran iskemik pada EKG sebanyak 21\%. Fibrilasi atrium yang terjadi pada PPOK eksaserbasi yang dirawat inap sebanyak $8-13 \% .10$

Pendekatan diagnosis PPOK dengan melihat gejala, riwayat eksaserbasi, nilai spirometri yang dikombinasikan dengan penyakit komorbid lebih merefleksikan PPOK dibandingkan hanya menilai hambatan aliran udara. Derajat PPOK berdasarkan GOLD dibagi atas A,B,C dan D. Kelompok A memiliki risiko ringan dan gejala sedikit yang ditandai dengan riwayat eksaserbasi 0 - 1 dalam 1 tahun, tidak terdapat riwayat rawat inap akibat eksaserbasi dan nilai CAT $<10$ atau mMRC 0 sampai 1 . Nilai spirometri termasuk kelompok GOLD 1 atau 2. Kelompok B memiliki risiko ringan dan gejala yang lebih banyak ditandai dengan riwayat eksaserbasi 0 - 1 dalam 1 tahun, tidak terdapat riwayat rawat inap akibat eksaserbasi dan nilai CAT $\geq 10$ atau $m M R C \geq 2$. Pasien kelompok C memiliki risiko tinggi, gejala sedikit ditandai dengan

Tabel 3. Pembagian kelompok PPOK berdasarkan VEP 1

\begin{tabular}{ll}
\hline Kelompok PPOK $($ VEP1/KVP $<0,70)$ & Nilai VEP1 \\
\hline GOLD 1 : Ringan & VEP1 $\geq 80 \%$ prediksi \\
GOLD 2 : Sedang & $50 \% \leq$ VEP1 $<80 \%$ prediksi \\
GOLD $3:$ Berat & $30 \% \leq$ VEP $1<50 \%$ prediksi \\
GOLD 4 : Sangat Berat & VEP1 $<30 \%$ prediksi \\
\hline Dikutip dari $(3)$ &
\end{tabular}


riwayat eksaserbasi $\geq 2$ dalam 1 tahun dan $\geq 1$ terdapat riwayat rawat inap akibat eksaserbasi dan nilai CAT $<10$ atau mMRC 0-1. Nilai spirometri termasuk kelompok GOLD 3 atau 4. Pasien kelompok D memiliki risiko tinggi, gejala banyak ditandai dengan riwayat eksaserbasi $\geq 2$ dalam 1 tahun, $\geq 1$ terdapat riwayat rawat inap akibat eksaserbasi dan nilai CAT $\geq 10$ atau $m M R C \geq 2$. Nilai spirometri termasuk kelompok GOLD 3 atau 4. Risiko eksaserbasi yang lebih tinggi dihubungkan dengan perburukan VEP1 yang lebih cepat dan status kesehatan. Nilai CAT lebih dari 10 dihubungkan dengan gangguan status kesehatan. Penelitian prospektif yang menyatakan peningkatan risiko eksaserbasi pada kelompok PPOK sesuai GOLD menyatakan bahwa eksaserbasi, rawat inap dan kematian berhubungan dengan perburukan hambatan aliran udara dan derajat berat spirometri. Gambar 1 menjelaskan pembagian PPOK berdasarkan gejala, spirometri dan riwayat eksaserbasi. ${ }^{3}$ sudah mencapai 2\% di Eropa, yang meningkat dua kali lipat dalam sepuluh tahun terakhir. Prevalensi fibrilasi atrium bervariasi menurut usia dan jenis kelamin. Berdasarkan usia, $<49$ tahun prevalensi FA 0,12\%$0,16 \%$, usia $60-70$ tahun prevalensi FA 3,7\%-4,2\% pada dan usia $>80 \%$ prevalensi FA $10 \%-17 \%$. Fibrilasi atrium lebih sering ditemukan pada laki-laki dengan perbandingan laki-laki dan perempuan $1,2: 1 .{ }^{12}$

Definisi FA berdasarkan American College of Cardiology/American Heart Association Task Force on Practice Guidelines and the European Society of Cardiology Committee for Practice Guidelines (ACC/AHA/ESC) tahun 2006 adalah takiaritmia supraventrikular yang ditandai dengan aktivasi atrium yang tidak terkoordinasi dengan menurunnya fungsi mekanik atrium. Pada Elektrokardiografi (EKG), FA ditandai dengan gelombang fibrilasi yang bergetar cepat, bervariasi pada amplitudo yang berakibat hilangnya gelombang $\mathrm{P}$, bentuk serta waktu yang

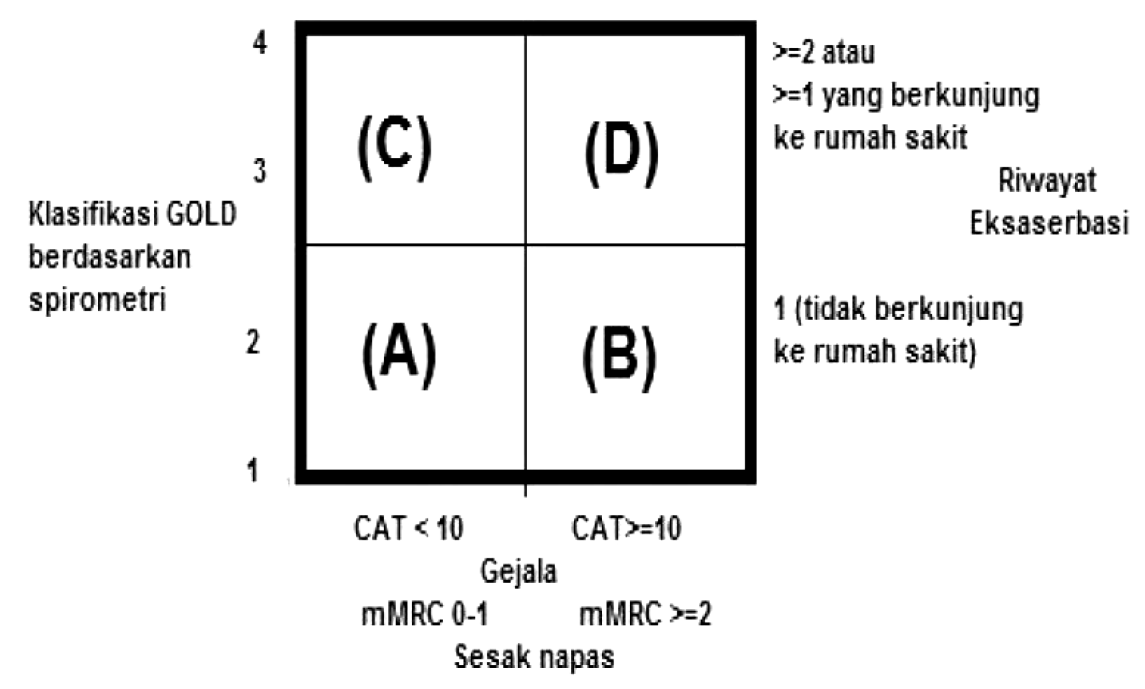

Gambar 1. Alur diagnosis PPOK berdasarkan GOLD 2015

Dikutip dari (3)

\section{Fibrilasi Atrium}

Dalam dua puluh tahun terakhir FA menjadi salah satu masalah kesehatan yang menyebabkan meningkatnya biaya perawatan Rumah Sakit (RS) di negara barat. Diperkirakan jumlah pasien dengan fibrilasi atrium pada tahun 2030 di Eropa sebanyak 14-17 juta jiwa dan 120.000-215.000 kasus baru FA per tahunnya. Prevalensi FA semakin meningkat. Angka penderita FA menyebabkan respon ventrikel yang cepat apabila konduksi atrioventrikular (AV) intak. Respon ventrikel terhadap FA tergantung dari elektrofisiologi nodus AV dan jalur konduksi lainnya, tonus simpatis dan vagal, ada tidaknya jalur konduksi tambahan dan obat-obatan. ${ }^{13}$

Definisi FA terbaru menurut the American College of Cardiology/American Heart Association Task Force on Practice Guidelines and the Heart Rhythm Society 
(ACC/AHA/HRS) tahun 2014 adalah takiaritmia supraventrikular yang tidak terkoordinasi dan tidak efektifnya aktivasi atrium. Pada gambaran EKG ditemukan interval R-R yang tidak teratur (saat terdapat Atrial Ventrikular/AV), tidak terlihatnya gelombang $\mathrm{P}$ dan aktivitas atrium yang tidak teratur. Perubahan hemodinamik FA dapat disebabkan karena kontrol laju ventrikel kurang optimal (terlalu cepat atau terlalu lambat), hilangnya koordinasi aktivitas atrium, variabilitas kecepatan pengisian ventrikel dan aktivasi saraf parasimpatik. ${ }^{14}$

Tabel 4. Faktor risiko dan petanda hayati/ biomarker untuk fibrilasi atrium

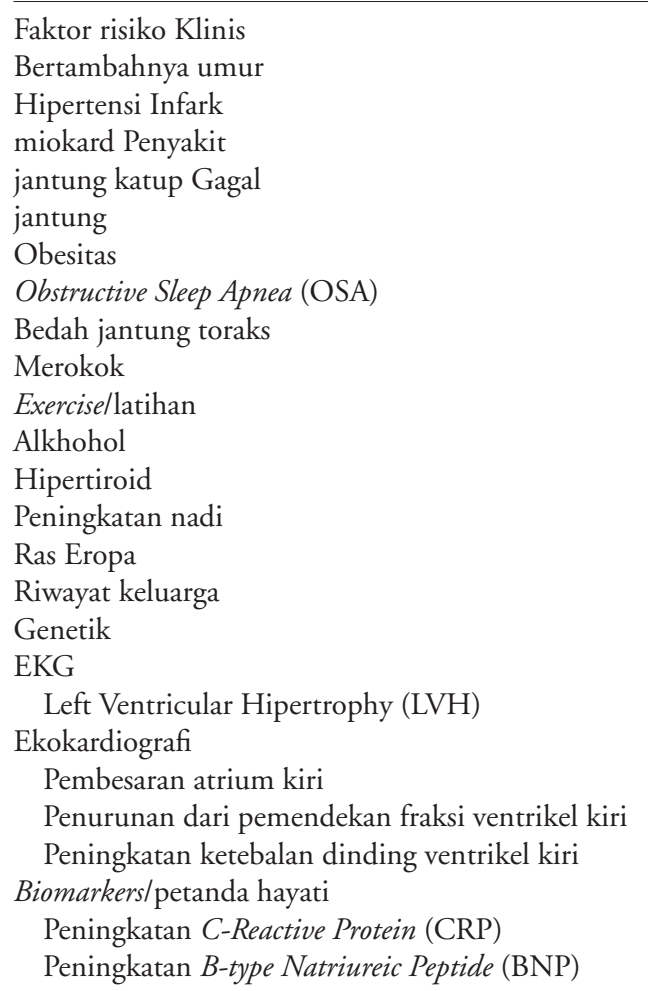

Dikutip dari (14)

Fibrilasi atrium berdasarkan The Task Force for the Management of Atrial Fibrillation of the European Society of Cardiology (ESC) tahun 2010 didefinisikan berdasarkan kriteria dibawah ini yang meliputi: ${ }^{15}$

1. Gambaran EKG memperlihatkan gambaran interval R-R yang tidak teratur (absolut aritmia) dan tidak mengikuti pola tertentu.

2. Tidak terlihat gelombang P pada EKG di semua sadapan. Gambaran $P$ yang tidak teratur dapat terlihat jelas di sadapan $\mathrm{V}_{1}$

3. Interval P-P pada fibrilasi atrium pendek $(200 \mathrm{~ms})$ setara dengan frekuensi denyut atrium 300 kali per menit.

Beberapa faktor risiko secara klinis, gambaran EKG, petanda biokimia berhubungan dengan risiko meningkatnya insiden FA. Sebuah analisis epidemiologi menemukan $56 \%$ dari populasi yang berisiko FA memiliki faktor risiko lebih dari satu. Oleh karena itu, untuk mencegah FA melalui pendekatan faktor risiko yakni dengan kontrol tekanan darah dan program penurunan berat badan. Banyak kasus yang berpotensi menyebabkan fibrilasi atrium yang bersifat reversibel seperti alkhohol, bedah jantung-toraks dan non kardiak, infark miokard, perikarditis, hipertiroid, pneumonia dan emboli paru. Tabel 4 dibawah ini adalah faktor risiko FA. ${ }^{14}$

\section{Klasifikasi fibrilasi atrium}

Klasifikasi FA berdasarkan The Task Force for the Management of Atrial Fibrillation of the European Society of Cardiology (ESC) tahun 2010 dibagi atas lima yakni awitan pertama (fist diagnosed), paroksismal, persisten, persisten menahun (long-standing persisten) dan permanen. Penjelasan klasifikasi adalah sebagai berikut: ${ }^{15}$

1. Fibrilasi Atrium awitan pertama/first diagnosed atrial fibrilation adalah FA pertama kali yang dialami, terlepas dari durasi dan beratnya gejala yang muncul akibat FA tersebut.

2. Fibrilasi atrium paroksimal/paroxysmal atrial fibrilation adalah FA yang muncul dan menghilang dalam 7 hari, berlangsung hanya dalam 48 jam. Waktu 48 jam merupakan tolak ukur karena pada FA yang muncul $>48$ jam kemungkinan kembali ke irama sinus lebih rendah dan perlu dipertimbangkan pemberian antikoagulan untuk menurunkan risiko stroke.

3. Fibrilasi atrium persisten/Atrial fibrilation persistent dapat ditegakkan bila $>7$ hari atau membutuhkan kardioversi sebagai metode terminasi, baik secara farmakologik atau elektrik.

4. Fibrilasi atrium persisten menahun/ Longstanding persistent atrial fibrilation adalah FA yang sudah berlangsung $\geq 1$ tahun saat dilakukan strategi kontrol irama (Rhytm control strategy)

5. Fibrilasi atrium permanen/permanent atrial fibrilation adalah sudah diketahui oleh pasien dan dokter. Intervensi kontrol irama secara agresif tidak menjadi prioritas dalam pengobatan. 
Klasifikasi ini berguna untuk manajemen klinis pasien fibrilasi atrium, terutama apabila gejala terkait FA perlu dipertimbangkan. Keputusan klinis perlu dipertimbangkan faktor individu dan komorbid. Silent atrial fibrilation (Silent $A F$ ) bersifat asimptomatik yang bermanifestasi terhadap komplikasiterkait FA seperti stroke iskemik atau takikardiomiopati yang didiagnosis berdasarkan EKG. Silent $A F$ dapat hadir sebagai salah satu bentuk temporal fibrilasi atrium. Aritmia cenderung berkembang dari persisten fibrilasi atrium (non self terminating atau membutuhkan kardioversi dalam 48 jam) ke long standing persistent atrial fibrialtion/fibrilasi atrium persisten menahun (>1 tahun) dan akhirnya fibrilasi atrium permanen (diterima). First onset atrial fibrilation / awitan pertama fibrilasi atrium dapat terjadi pada serangan pertama atau berulang dan sudah dianggap menjadi permanen. Berbagai tipe

FA dapat dilihat pada gambar 2 di bawah ini. ${ }^{15}$ sampai 170 kali per menit. Fibrilasi atrium merupakan sumber morbiditas dan kematian karena terjadi kerusakan fungsi jantung dan meningkatkan risiko stroke. Gambar 3 menggambarkan EKG dengan FA. Tidak terdapat gelombang $\mathrm{P}$ yang digantikan oleh aktivitas listrik yang tidak teratur. Laju ventrikel irregular dan kacau. ${ }^{16}$

Gejala FA kadang bersifat asimptomatik. Pada sebagian orang dapat muncul sebagai gagal jantung atau kolaps kardiovaskular. Pasien sebagian besar mengeluhkan palpitasi, sesak dapas, kelelahan, pusing dan nyeri dada. Oleh karena gejalanya non spesifik, tidak dapat mendiagnosis dan menentukan onset dari FA. Pemeriksaan standar yang digunakan untuk mengevaluasi fungsi jantung dan faktor komorbid termasuk dengan EKG, pemeriksaan darah lengkap, pemeriksaan profil metabolik lengkap, thyroid stimulating hormone (TSH), foto toraks dan ekokardiografi. Ekokardiografi memberikan informasi

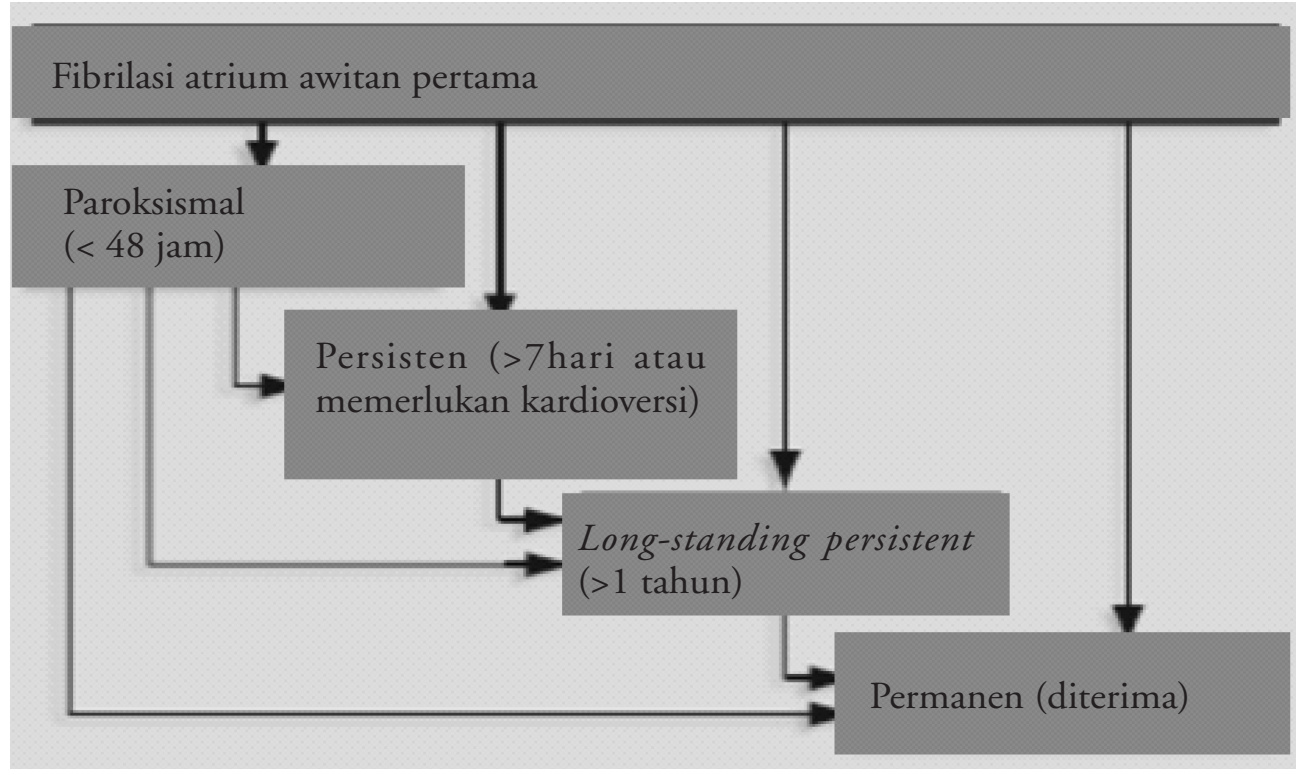

Gambar 2. Tipe fibrilasi atrium

Dikutip dari (15)

\section{Diagnosis Fibrilasi atrium}

Pada gambaran EKG pada FA ditemukan penggantian gelombang $\mathrm{P}$ dengan aktivasi sinkron dari atrium dengan gelombang yang cepat dalam ukuran, amplitude dan waktu yang berbeda. Kompleks QRS menjadi sempit, respon ventrikel cepat berkisar 90 mengenai ukuran jantung, ukuran ruang jantung, anatomi dan fungsi katup, kelainan gerakan dinding, fungsi sistolik dan diastolik dan penyakit perikardial. Bila dicurigai secara klinis penyakit jantung iskemik, maka kadar isoenzim kreatin kinase dan troponin harus diperoleh. Beberapa pasien diperlukan pemeriksaan tambahan seperti stress testing dan studi elektrofisiologi. Tabel 5 menunjukkan evaluasi awal untuk FA. ${ }^{16}$ 


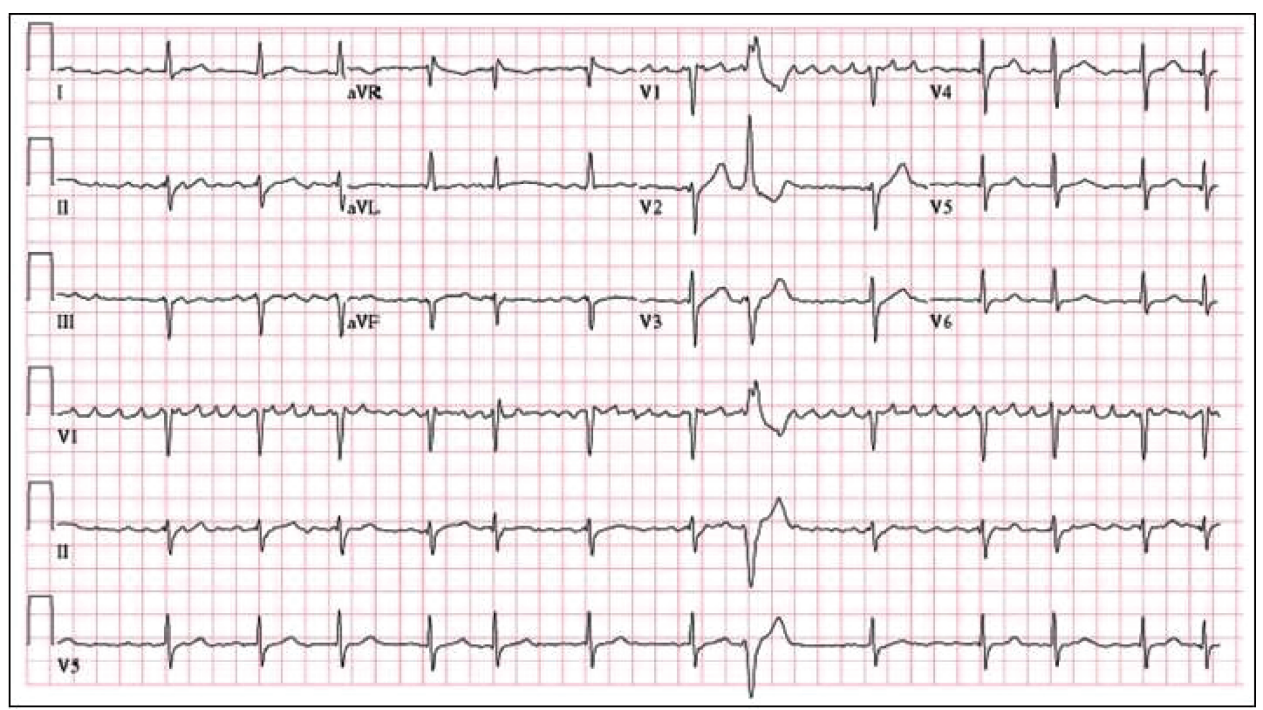

Gambar 3. Gambaran EKG ada fibriasi atrium

Dikutip dari (16)

Tabel 5. Evaluasi awal fibrilasi atrium.

\begin{tabular}{ll}
\hline Pemeriksaan & Tujuan \\
\hline Foto toraks & $\begin{array}{l}\text { Mengidentifikasi kemungkinan penyakit paru. } \\
\text { (pneumonia, kongesti vaskular, PPOK) }\end{array}$ \\
$\begin{array}{l}\text { Darah lengkap } \\
\text { Profil metabolik lengkap }\end{array}$ & Mengidentifikasi kondisi komorbid. (anemia, infeksi) \\
& memperberat fibrilasi atrium. \\
& - Menilai fungsi ginjal dan hepar, serta kadar glukosa darah. \\
Ekokardiografi & Menilai ukuran dan besar jantung; tekanan dan ukuran ruang jantung; \\
& efusi perikardial; kelainan gerakan dinding; fungsi sistolik dan diastolik. \\
1EKG & Mendiagnosis fibrilasi atrium dan mengidentifiksi kelainan aritmia \\
& lainnya seperti atrial flutter dan takikardi. \\
& $-\quad$ Mengidentifikasi kondisi jantung (hipertrofi ventrikel kiri, \\
Pemeriksaan thyroid-stimulating hormone/TSH & iskemi, keregangan/strain, cedera/injury) \\
\hline
\end{tabular}

Dikutip dari (16)

Pemeriksaan fisis yang ditemukan pada FA antara lain nadi yang irregular, pulsasi vena jugularis yang irregular, intensitas bunyi jantung pertama yang bervariasi atau tidak terdengar keempat bunyi yang terdengar selama irama sinus. Temuan pemeriksaan fisis ini ditemukan pula pada pasien dengan atrial flutter, kecuali didapatkan irama regular dan osilasi vena yang cepat sesekali terlihat pada jugularis. ${ }^{13}$ Evaluasi klinis juga termasuk Skor EHRA untuk FA (EHRA score of AF-related symptoms) merupakan sistem skoring yang dibuat oleh EHRA (European Heart Rhythm Association) untuk menentukan berat ringannya klasifikasi penderita fibrilasi atrium berdasarkan gejalanya. Pembagian skor EHRA ini terdiri atas lima kelompok yaitu EHRA I, II, III dan IV. EHRA I menunjukkan tidak ada gejala. EHRA II menunjukkan gejala ringan dan aktivitas seharihari tidak terganggu. EHRA III menunjukkan gejala berat dan dan aktivitas sehari-hari terganggu. EHRA $\mathrm{V}$ menunjukkan gejala yang menyebabkan disabilitas dan tidak dapat melanjutkan aktivitas normal sehari-hari. Klasifikasi Atrial Fibrilation (AF) related symptoms (skor EHRA) akan diringkas dalam Tabel 6 di bawah ini. ${ }^{15}$ 
Tabel 6. Skor EHRA

\begin{tabular}{ll}
\hline Klasifikasi $A F$ & related symptoms (skor EHRA) \\
Kelas EHRA & Keterangan \\
\hline EHRA I & $\begin{array}{l}\text { Tidak ada gejala } \\
\text { Gejala ringan/mild symptoms; aktivitas sehari-hari } \\
\text { tidak terganggu. }\end{array}$ \\
EHRA III & $\begin{array}{l}\text { Gejala berat/severe symptoms; aktivitas sehari-hari } \\
\text { terganggu }\end{array}$ \\
EHRA IV & $\begin{array}{l}\text { Gejala disabilitas/disabling symptoms } ; \text { tidak dapat } \\
\text { melanjutkan aktivitas normal sehari-hari. }\end{array}$ \\
\end{tabular}

Dikutip dari (15)

\section{Patofisologi Fibrilasi Atrium pada PPOK}

Fibrilasi atrium terjadi ketika kelainan struktur dan/atau elektrofisiologi merubah atrium untuk membentuk impuls yang tidak normal dan/ atau lebih cepat. Kelainan ini disebabkan oleh mekanisme patofisiologis yang beragam sehingga FA menjadi fenotip untuk beberapa jalur penyakit yang mekanismenya sulit dipahami. Penyakit lain seperti amiloidosis, hemokromatosis dan sarkoidosis dapat menyebabkan fibrilasi atium. Faktor penyebab ekstra kardiak yang dapat menyebabkan fibrilasi atrium

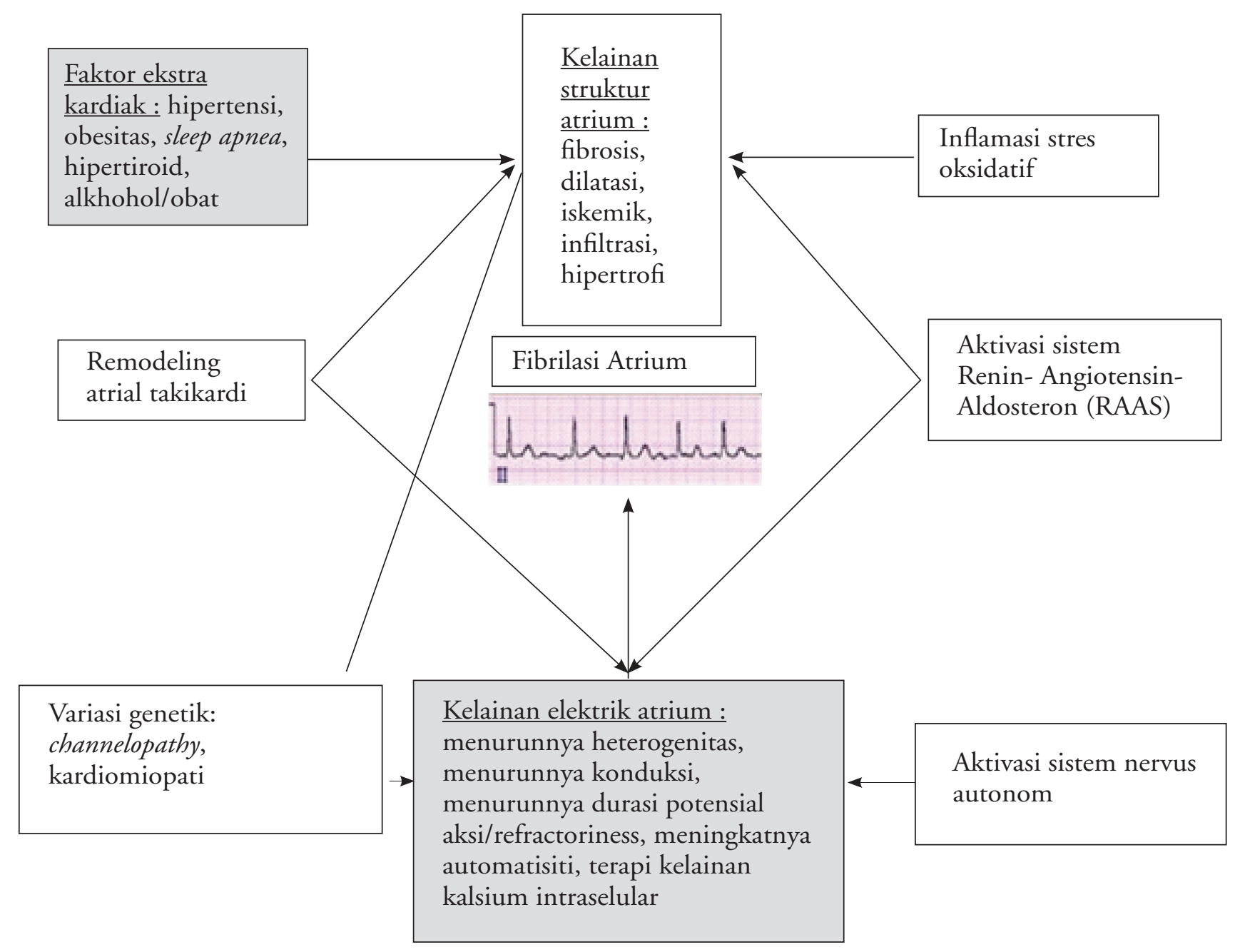

Gambar 4. Mekanisme fibrilasi atrium Dikutip dari (14) 
antara lain hipertensi, sleep apnea, obesitas, penggunaan alkhohol/obat-obatan dan hipertiroid. Gambar 4 dibawah ini menunjukkan skema mekanisme yang terjadi pada FA. ${ }^{12}$ Berbagai faktor yang diduga menjadi penyebab aritmia pada PPOK antara lain hipoksemia, asidosis, alkalosis, hipokalemi, obat-obatan (digitalis, metilxantin, agonis beta adrenergik, propelan aerosol, steroid), etanol, penyakit jantung koroner, kor pulmonal, dan stimulasi sistem adrenergik dan/atau antikolinergik. ${ }^{17}$

\section{Faktor atrium}

Perubahan histopatologi yang sering terjadi pada fibrilasi atrium adalah fibrosis atrium dan hilangnya massa otot atrium. Fibrosis pada atium mendahului timbulnya fibrilasi atrium. Fibrosis intersisial mungkin ditimbulkan akibat apoptosis yang menyebabkan hilangnya miofibril, akumulasi glikogen, gangguan penyatuan sel pada gap junctions. ${ }^{13}$ Gangguan struktur atrium antara lain inflamasi, fibrosis, hipertrofi yang mendasari penyakit jantung terkait dengan hipertensi, penyakit jantung koroner, penyakit jantung katup, kardiomiopati dan gagal jantung. Hal ini menyebabkan pelebaran atrium kiri, dilatasi atrium dan menyebabkan tekanan pada dinding atrium. Kelainan struktur ini menyebabkan terdapat heterogenitas dalam mengubah konduksi impuls dan/atau refrakter, dan menghasilkan substrat arrhythmogenic. ${ }^{14}$

Penelitian cross sectional yang dilakukan Yildiz $\mathrm{dkk}$, pada pasien PPOK didapatkan peningkatan total durasi QRS dibandingkan dengan kelompok kontrol. Ventrikular aritmia pada PPOK berhubungan dengan peningkatan QT dispersion (QTd) karena perubahan otonom. Peningkatan dinding bebas ventrikel, ketebalan septum interventrikel, dimensi interna ventrikel kanan, dan diameter atrium kanan didapatkan pula pada pasien PPOK. Fraksi ejeksi/ ejection fraction dan fraction shortening menurun pada pasien PPOK dibandingkan dengan kontrol. Ketebalan dinding posterior ventrikel kiri, diameter internal (diastolik), mass index, diameter atrium kiri dan denyut jantung sama pada pasien PPOK dan kelompok kontrol. ${ }^{18}$

Penelitian Asad dkk mendapatkan Gelombang P pada pasien PPOK tidak konstan, dan pada PPOK eksaserbasi didapatkan peningkatan peningkatan amplitudo yang menunjukkan regangan pada atrium kanan. ${ }^{19}$ Hipertrofi dan kelainan fungsional ventrikel kanan pada PPOK banyak ditemui. Hipertrofi ventrikel kiri juga terdapat pada pasien PPOK yang disebabkan perubahan biokimia dan anatomi, termasuk menurunnya norepinefrin dan kelainan histokimia serabut saraf, penekanan aktivitas miofibrin adenosin trifosfat dan meningkatnya serat kolagen. Tekanan ventrikel kanan yang meningkat pada hipertensi pulmoner menghasilkan pergeseran ke kiri ventricular septal shift yang ditandai pada akhir sistol dan awal diastol dengan geometri distorsi ventrikel kiri, sehingga terjadi perpanjangan waktu relaksasi isovolumetrik ventrikel kiri dan berkurangnya pengisian awal diastolik. ${ }^{20}$

\section{Inflamasi}

Aktivasi leukosit memegang peranan penting dalam jalur inflamasi yang mendasari fibrilasi atrium. Sitokin dan kemokin ikut andil dalam mengatur dan mengaktifkan leukosit, hal ini dinilai mediator potensial dalam pembentukan trombus terkait fibrilasi atrium (AF-related thrombosis). Mediator inflamasi tersebut antara lain $C$-reactive protein (CRP), tumor necrosis factor $\alpha$ (TNF- $\alpha$ ), interleukine (IL)-6, IL-8, dan monoattractant protein 1 (MCP-1). Meningkatnya nilai C-Reactive Protein (CRP) dapat memprediksi risiko terjadinya fibrilasi atrium dan terdapatnya sumbatan spontan kontras pada atrium kiri yang terlihat pada ekokardiografi, terutama pada pasien yang memiliki risiko stroke rendah atau sedang. Meningkatnya kadar TNF- $\alpha$ pada plasma dan jaringan atrium kiri merupakan korelasi positif terhadap diameter atrium kiri pada pasien dengan penyakit jantung reumatik dan fibrilasi atrium kronik. Meningkatnya TNF $\alpha$ juga dilaporkan pada pasien fibrilasi atrium persisten daripada fibrilasi paroksismal. Rendahnya serum IL-2 pada pasien rawat inap, menunujukkan keberhasilan terapi kardioversi dengat gejala onset yang baru. Meningkatnya kadar IL-6 berkorelasi dengan durasi dan terdapatnya FA serta meningkatnya diameter atrium kiri. Beberapa penelitian menghubungkan peningkatan IL-8 dengan fibrilasi atrium permanen. MCP-1 dilaporkan meningkat secara signifikan selama fibrilasi atrium, dan mencapai kadar tertinggi pada kasus trombus atrium. ${ }^{21}$

Andreas dkk mendapatkan inflamasi menetap pada PPOK derajat sedang sampai berat, yang memiliki komorbid kardiovaskular, ditandai dengan kenaikan CRP. Pada PPOK terdapat pula aktivasi neurohumoral, yaitu tedapatnya inflamasi, kakeksia, efek pada ventilasi 
dan disfungsi otot skeletal yang berkontribusi pada patogenesis PPOK, dan melibatkan disfungsi otot pernapasan. Gambar 5 menjelaskan tentang kaitan

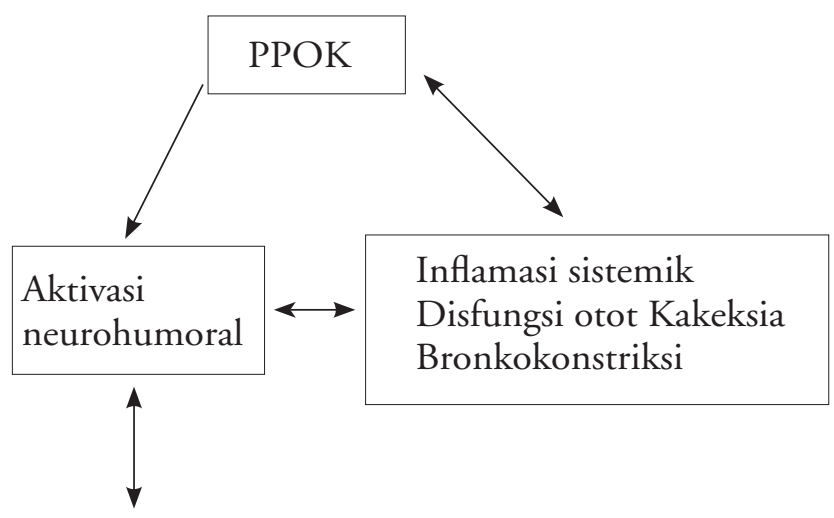

Penyakit

kardiovaskular

Gambar 5. Kaitan aktivasi neurohumoral dengan PPOK Dikutip dari (22)

aktivasi neurohumoral dengan PPOK. ${ }^{22}$

\section{Aktivasi sistem renin-angiotensin-aldosteron/ The Renin-Angiotensin-Aldosterone System (RAAS)}

Aktivasi RAAS mencetuskan efek elektrofisiologi dan struktural di atrium dan ventrikel yang akan menyebabkan aritmia. Selain berdampak negatif pada efek hemodinamik, aktivasi dari beberapa kaskade sinyal sel, terjadi peningkatan kalsium intraselular, hipertrofi, apoptosis, pelepasan sitokin dan mediator inflamasi, stres oksidatif dan produksi faktor terkait pertumbuhan yang akan merangsang fibrosis. Komponen RAAS (termasuk Angiotensin-II, Angiotensin-Converting Enzyme /ACE dan aldosteron) yang disintesis secara lokal di atrial miokardium dan meningkat saat atrial tachypacing dan fibrilasi atrium. Varian pada gen ACE akan meningkatkan konsentrasi plasma angiotensin II terkait risiko FA, sedangkan ekspresi berlebihan kardio selektif ACE menyebabkan dilatasi arteri, fibrosis dan meningkatkan kecurigaan fibrilasi atrium. ${ }^{14}$ Angiotensin II diregulasi dalam merespon peregangan atrium dan jaringan atrium pada pasien dengan FA permanen yang ditandai oleh peningkatan ekspresi ACE. Penghambatan angiotensin mungkin dapat mencegah FA dengan menurunkan fibrosis. ${ }^{13}$
Efek sistemik yang ditimbulkan PPOK menyebabkan edema masif dan disertai penurunan aliran darah ke ginjal sehingga menyebabkan meningkatnya kadar renin, aldosteron, vasopresin dan peptida natriuretik. Kondisi ini yang kita sebut dengan kor pulmonal. Pasien dengan edema akibat PPOK mengalami retensi natrium dan air yang berat, penurunan aliran ginjal dan filtrasi glomerulus, serta aktivasi neurohumoral yang menyerupai edema pada pasien penyakit miokard. Pada pasien PPOK didapatkan cardiac output yang normal, resistensi vaskular sistemik dan tekanan darah arteri yang rendah. Pada tekanan darah arteri yang rendah menyebabkan perangsangan aktivasi neurohumoral serta retensi natrium dan air. Hiperkapnia menyebabkan turunnya perfusi ginjal oleh karena menurunnya resistensi perifer dan baroreseptor arteri menjadi aktif, sehingga meningkatkan produksi norepinefrin dan sistem RAAS. ${ }^{23}$

\section{Penyakit jantung koroner (PJK)}

PPOK merupakan faktor risiko penting terjadinya aterosklerosis. Penurunan sedikit fungsi faal paru, akan meningkatkan risiko stroke, penyakit jantung iskemik, dan kematian mendadak 2-3 kali lipat, terlepas dari faktor risiko lainnya. Hambatan aliran udara merupakan faktor risiko penting untuk cedera jantung. Peningkatan CRP, akan meningkatkan risiko 2 kali lipat yang memainkan peran dalam inflamasi sistemik dan berkembang menjadi penyakit jantung iskemik. Meningkatnya produksi sitokin proinflamasi dan faktor jaringan oleh monosit, maka akan meningkatkan low density lipoprotein (LDL) oleh makrofag dan menginduksi secara langsung ekspresi sel endotel. CRP dapat deposit ke dinding arteri selama aterogenesis, berinteraksi dengan mediator inflamasi lain membuat foam cells yang membentuk plak aterosklerosis. Pasien dengan obstruksi jalan napas berat, dikaitkan dengan inflamasi sel netrofil yang meningkat sehingga membentuk plak aterosklerosis. ${ }^{24}$

Hipoksia pada pasien PPOK juga dapat memperberat penyakit jantung koroner yang menimbulkan FA. Penelitian Stein dkk menemukan pada pasien PPOK terdapat rerata kompleks prematur atrial 189 kali dan pada pasien bukan PPOK didapatkan rerata kompleks pematur atrial 15 kali melalui pemeriksaan Holter 24 jam. ${ }^{25}$ Incalzi dkk juga menemukan hal serupa bahwa munculnya kompleks prematur atrial pada PPOK, berhubungan dengan hiperkarbia dan hipoksia. ${ }^{26}$ 


\section{Gangguan tonus otonom}

Tonus otonom memegang peranan penting dalam munculnya FA. Salah satu faktor yang mempengaruhi konduksi nodus atrioventrikular (nodus AV) adalah refrakter intrinsik dari nodus AV. Ganglion otonom mengandung saraf simpatis dan parasimpatis. Peningkatan parasimpatis dan pengurangan tonus simpatik memberikan efek dromotropik negatif pada konduksi nodus AV. Tonus simpatis juga memberikan efek kronotropik tersembunyi konduksi pada nodus AV. Fluktuasi tonus otonom menghasilkan respon ventikel berbeda pada fibrilasi atrium, seperti laju ventrikel rendah selama tidur namun meningkat saat latihan. ${ }^{13}$

Hipoksia dapat menyebabkan meningkatnya saraf simpatis yang berakhir dapat mencetuskan aritmia. ${ }^{27}$ Hipoksia kronik pada PPOK diketahui dapat menyebabkan kondisi hiperadrenergik. Hipoksia akut juga dapat meningkatkan mikroneurografik dari aktivitas simpatis. ${ }^{22}$ Merokok dalam jangka waktu lama secara signifikan akan mengurangi kapasitas vital $(\mathrm{KV})$ paru dan merokok memiliki faktor risiko untuk terjadinya fibrosis paru, gangguan vaskularisasi paru yang akhirnya menyebabkan hipertensi pulmoner. ${ }^{28}$ Kondisi hiperkapnia akan memicu sistem simpatis dan semakin tingginya kadar katekolamin. Pada pasien PPOK terutama pada eksaserbasi akut, didapatkan kadar katekolamin yang tinggi. ${ }^{22}$

\section{Farmakologis}

Kortikosteroid dosis tinggi dihubungkan dengan risiko timbulnya FA. Beberapa mekanisme yang menyebabkan berkembangkan FA yang diterapi dengan kortikosteroid dosis tinggi. Pertama, kortikosteroid dosis tinggi menyebabkan secara lokal kehilangan kalium secara langsung pada membran sel yang dapat menyebabkan aritmia. Kedua, glukokortikosteroid dosis tinggi mempunyai efek mineralokortikosteroid, seperti retensi natrium dan cairan yang menyebabkan hipertensi, pembesaran atrium kiri dan gagal jantung kongestif yang kita ketahui sebagai faktor risiko fibrilasi atrium. Van der Hooft dkk melakukan penelitian terhadap 385 pasien kasus baru fibrilasi atrium, dan didapatkan risiko timbulnya fibrilasi atrium secara bermakna lebih tinggi pada pasien yang menerima kortikosteroid dosis tinggi oral atau parenteral yakni dosis harian $>7,5 \mathrm{mg}$ prednison selama satu bulan..$^{29}$ Huerta dkk melaporkan terdapat hubungan antara penggunaan oral kortikosteroid jangka pendek dan teofilin dengan aritmia jantung (termasuk fibrilasi atrium) pada pasien PPOK. ${ }^{30}$

Pengguaan $\beta$-2 agonis (salbutamol, terbutalin, fenoterol, prokaterol, salmeterol, formoterol) pada pasien PPOK dikaitkan dengan meningkatnya risiko miokard infark, gagal jantung kongestif, henti jantung dan kematian jantung akut. Stimulasi $\beta$-2 adrenergik akan meningkatkan denyut jantung, kebutuhan oksigen miokard, dan menyebabkan cedera atau nekrosis miokard secara langsung yang pada akhirnya menyebabkan iskemia, gagal jantung kongestif progresif atau kematian mendadak. Sinus takikardi adalah kondisi aritmia supraventrikular pertanda kondisi berat patologi yang mendasari iskemia, infark miokard atau gagal jantung kongestif. Sinus takikardi selain petanda stimulasi parasimpatis, juga mempunyai prognosis buruk kardiovaskular. Peningkatan denyut jantung telah terbukti meningkatkan risiko kardiomiopati, PJK, fatal infark miokard, dan kematian mendadak. Stimulasi $\beta$-2 adrenergik menyebabkan hipokalemi, yang akhirnya meningkatkan risiko takikardi ventrikular dan fibrilasi atrium. Penggunaan kortikosteroid dan diuretik pada PPOK menyebabkan menurunnya kadar kalium. Sebuah meta analisis Salpeter dkk didapatkan risiko sinus takikardi akibat pemakaian $\beta$-2 agonis adalah 3,06. ${ }^{31}$

Reseptor $\beta$-2 adrenergik terdistribusi luas pada sistem respirasi dan kardiovaskular. Sering kali klinisi tidak merekomendasikan penggunaan $\beta$ bloker pada pasien PPOK yang mendapat inhalasi $\beta-2$ agonis, karena akan memperberat kardiovaskular sebagai komorbid. Penelitian terkini menunjukkan inhalasi $\beta-2$ agonis kerja singkat (salbutamol, terbutalin, fenoterol, prokaterol) dan kerja lama (indakaterol, salmeterol, formoterol) lebih dari 1 tahun dianggap aman pada pasien tanpa penyakit kardiovaskular atau dengan penyakit kardiovaskular yang stabil (aritmia, PJK atau gagal jantung). Beta bloker kardioselektif adalah reseptor selekif $\beta$ bloker mempengaruhi fungsi jantung. Beta bloker yang bersifat tidak kardioselektif adalah $\beta$ bloker yang bekerja pada semua beta adrenergik reseptor, yang dapat menyebabkan bronkospasme, efek ekstra kardiak, namun juga mempengaruhi stimulasi reseptor $\alpha$ yang menyebabkan vasodilatasi perifer dan koroner. Pemakain $\beta$ bloker yang bersifat kardioselektif (tanpa efek intrinsik simpatomimetik) seperti metorolol, bisoprolol, dan nebivolol sangat dianjurkan pada pasien PPOK. ${ }^{32}$

Berdasarkan GOLD 2015, merekomendasikan 
bronkodilator, kortikosteroid dan Phosphodiesterase-4 Inhibitor (PDE-4) sebagai terapi utama. Penggunaan bronkodilator inhalasi dengan kombinasi $\beta 2$ agonis dan antikolinergik (evidence $A$ ), penggunaan metilsantin oral kurang disarankan karena sedikit efikasi dan banyak terdapat efek samping. Kortikosteroid inhalasi direkomendasikan pada pasien PPOK berat dan sangat berat yang tidak terkontrol dengan bronkodilator kerja lama (evidence A). Penggunaan monoterapi kortikosteroid jangka panjang dan kortikosteroid oral tidak disarankan. $^{3}$

\section{Komplikasi Fibrilasi Atrium Pada Ppok}

Mekanisme tromboemboli pada fibrilasi atrium antara lain faktor risiko yang berhubungan dengan stasis atrium, disfungsi endotel dan hiperkoagulabilitas. Pembentukan trombus pada left atrial appendage (LAA) menyebabkan stroke iskemik dan kardioemboli pada pasien fibrilasi atrium. Setelah tindakan kardioversi baik dengan elektrik, spontan ataupun dengan farmakologis juga dapat menyebabkan peningkatan risiko tromboemboli. Pengamatan dan evaluasi klinis diperlukan, $80 \%$ tromboemboli terjadi pada 3 hari pertama, dan hampir semua terjadi dalam 10 hari. Hubungan yang kuat didapatkan antara hipertensi dan stroke pada FA, terutama disebabkan oleh emboli yang berasal dari LAA. Usia lanjut merupakan faktor risiko untuk aterosklerosis dan pembentukan plak di arkus aorta dengan independen stroke pada fibrilasi atrium. Umur merupakan risiko potensial ketika dikombinasi dengan faktor risiko lain seperti hipertensi, jenis kelamin, usia $>75$ tahun dengan fibrilasi atrium yang merupakan faktor risiko stroke. Sistem skoring berdasarkan $\mathrm{CHA}_{2} \mathrm{DS}_{2}$ VASc merupakan sebuah perhitungan risiko stroke pada FA, terdapat kelompok pasien dengan karakteristik tertentu untuk mengalami kejadian tromboemboli. ${ }^{13}$

Terapi anti koagulan berdasarkan skoring $\mathrm{CHA}_{2} \mathrm{DS}_{2}$ VASc dinilai dari jumlah skor tersebut. Skor $\mathrm{CHA}_{2} \mathrm{DS}_{2} \mathrm{VASc} \geq 2$ diberikan anti koagulan oral seperti vitamin $\mathrm{K}$ antagonis dengan dosis disesuaikan untuk mecapai international normalized ratio/ INR 2-3 dan tidak ada kontraindikasi. Skor $\mathrm{CHA}_{2} \mathrm{DS}_{2}$ VASc 1 diberikan antikoagulan oral atau aspirin 75$325 \mathrm{mg}$ per hari, namun pemberian antikoagulan oral lebih dianjurkan dibandingkan aspirin. Skor $\mathrm{CHA}_{2} \mathrm{DS}_{2}$ VASc 0 diberikan aspirin 75-325 mg per hari atau tanpa antikoagulan, lebih dianjurkan tanpa pemberian antikoagulan dibandingkan dengan aspirin. Terapi tromboprofilaksis pada pasien fibrilasi atrium dapat dilihat di tabel 9 di bawah ini. ${ }^{15}$

Pemberian antikoagulan memiliki risiko perdarahan. Risiko perdarahan pada pasien fibrilasi atrium yang mendapat antikoagulan dapat diperkirakan dengan menggunakan sistem skoring HASBLED. Terdapat 7 karakteristik klinik pada sistem scoring ini. Definisi hipertensi adalah jika tekanan sistolik $>160 \mathrm{mmHg}$. Abnormalitas fungsi ginjal didefinisikan apabila terdapat dialisis kronik atau transplantasi ginjal atau kadar serum kreatinin $\geq 200 \mu \mathrm{mol} / \mathrm{L}$. Abnormalitas fungsi hati didefinisikan apabila terdapat hepatitis kronik (sirosis) atau kadar bilirubin $>2 \mathrm{x}$

Tabel 9. Terapi tromboprofilaksis pada fibrilasi atrium

\begin{tabular}{|c|c|c|}
\hline Kategori risiko & Skor CHA2DS2VASc & Rekomendasi antitrombotik \\
\hline $\begin{array}{l}1 \text { faktor risiko mayor } \\
\text { atau }>2 \text { faktor risiko } \\
\text { bukan mayor (klinis) }\end{array}$ & $>2$ & $\begin{array}{l}\text { Antikoagulan oral (oral } \\
\text { anticoagulan/OAC) }\end{array}$ \\
\hline $\begin{array}{l}1 \text { faktor risiko bukan } \\
\text { mayor (klinis) }\end{array}$ & 1 & $\begin{array}{l}\text { OAC, atau } \\
\text { Aspirin } 75-325 \mathrm{mg} / \mathrm{hari} \\
\text { Anjuran :antikoagulan } \\
\text { oral dibandingkan aspirin }\end{array}$ \\
\hline Tidak ada faktor risiko & 0 & $\begin{array}{l}\text { Aspirin } 75-325 \mathrm{mg} / \mathrm{hari} \\
\text { atau } \\
\text { Tidak ada pemberian antitrombotik } \\
\text { Anjuran : tidak ada } \\
\text { pemberian antitrombotik } \\
\text { dibandingkan aspirin }\end{array}$ \\
\hline
\end{tabular}

Dikutip dari (15) 
nilai normal atau kadar aspartat aminotransferase/ alanin aminotransferase/alkalifosfatase $>3 \mathrm{x}$ nilai normal. Perdarahan/bleeding adalah mengalami riwayat perdarahan sebelumnya dan ada predisposisi (perdarahan diatesis, anemia). INR labil apabila didapatkan kadar tidak stabil atau tingginya kadar INR atau waktu rata- rata terapeutik yang rendah $(<$ 60\%). Obat-obatan seperti antiplatelet, anti inflamasi non steroid/AINS, atau penyalahgunaan alkhohol. Apabila skor $\geq 3$ pasien dikatakan mempunyai risiko tinggi perdarahan sehingga diperlukan perhatian dan evaluasi secara teratur selama pemberian terapi antitrombotik Parameter yang digunakan tercantum dalam tabel $10 . .^{15,33}$

Tabel 10. Sistem skoring HASBLED untuk menilai risiko perdarahan pada pasien AF dengan penggunaan antikoagulan

\begin{tabular}{lc}
\hline Karakteristik klinis & Skor \\
\hline Hipertensi & 1 \\
Abnormalitas fungsi ginjal dan hati & 1 atau 2 \\
Stroke & 1 \\
Perdarahan (Bleeding) & 1 \\
INR labil & 1 \\
Usia tua (Elderly) dengan usia $>65$ years & 1 \\
Obat-obatan (drugs) dan alkohol & 1 atau 2 \\
\hline Dikutip dari (22)
\end{tabular}

Pemberian vitamin $\mathrm{K}$ antagonis (VKAs) seperti warfarin, merupakan antikoagulan oral aktif yang diperbolehkan digunakan dalam jangka waktu lama. Meskipun efektif, tetapi memiliki banyak kekurangan seperti yang disebutkan dalam tabel 11.34 Pemberian new oral anti coagulants (NOACs) untuk pencegahan stroke pada atrial fibrilasi terdiri atas 2 klasifikasi, yaitu menghambat trombin secara langsung (oral) misalnya dabigratan dan menghambat faktor Xa secara langsung misalnya rivaroxaban dan apixaban. Sama halnya dengan VKAs yang menginhibisi faktor koagulasi vitamin $\mathrm{K}$ dependen (faktor II, VII, IX,dan X), obat ini juga menghambat aktivitas koagulasi. Rivaroxaban secara signifikan mengurangi fatalnya perdarahan, namun juga dapat meningkatkan risiko perdarahan saluran cerna. Penelitian RE-LY, dabigatran etexilate secara signifikan mengurangi risiko stroke dan emboli sistemik. Penelitian double blind yang dilakukan ROCKET menyebutkan rivaroxaban lebih inferior dibandingkan warfarin untuk mencegah risiko stroke dan emboli sistemik. Penelitian ARISTOTLE, didapatkan perubahan signifikan dalam mengurangi risiko stroke atau emboli sistemik sebanyak $21 \%$ dengan apixaban dibandingkan dengan warfarin. Keuntungan dari NOACs dapat dilihat di tabel 12.34,35

Penelitian obeservasi longitudinal oleh Huang dkk pada 227 kelompok PPOK dengan fibilasi atrium, dibandingkan dengan kelompok bukan PPOK yang

Tabel 11. Keterbatasan vitamin $\mathrm{K}$ antagonis (VKAs)

\begin{tabular}{ll}
\hline Keterbatasan & Implikasi klinis \\
\hline Onset lambat dan kerja offset & $\begin{array}{l}\text { Membutuhkan bridging dengan kerja } \\
\text { cepat dari anti koagulan }\end{array}$ \\
Variasi individu mempengaruhi efek antikoagulan & Variabilitas dosis yang dibutuhkan \\
Narrow therapeutic window & Membutuhkan monitor rutin koagulasi \\
Terdapat interaksi makanan dan obat lain & Dietary precautions \\
Mengurangi sintesis vitamin K- protein dependen & Risiko nekrosis kulit pada pasien \\
& dengan defisiensi protein C atau S \\
& Potensial menyebabkan osteoporosis \\
\hline
\end{tabular}

Dikutip dari (34)

Tabel 12. Keuntungan NOACs

\begin{tabular}{ll}
\hline Keuntungan & Implikasi klinis \\
\hline Onset cepat & Tidak membutuhkan bridging \\
Dapat memprediksi efek antikoagulan & Tidak memerlukan monitor rutin koagulasi \\
Spesifik target enzim koagulasi & Risiko rendah \\
Potensial rendah interaksi makanan & Tidak membutuhkan dietary precautions \\
Potensial rendah interaksi obat & Efek samping rendah \\
& Membutuhkan beberapa pembatasan obat \\
\hline
\end{tabular}

Dikutip dari (34) 
sama-sama diberi warfarin, dalam pengamatan 1 tahun didapatkan kasus kematian lebih tinggi pada kelompok PPOK dengan fibrilasi atrium $(\mathrm{P}<0,001)$ dibandingkan kelompok bukan PPOK $(\mathrm{P}<0,027)$. Kejadian stroke pada kedua kelompok didapatkan hasil sebanding $(\mathrm{P}=$ 0,788). Setelah dilakukan uji multivariat didapatkan PPOK merupakan faktor risiko independen penyebab seluruh kematian selama 1 tahun, kematian karena kardiovaskular, tetapi bukan faktor risiko untuk stroke. Pemberian anti koagulan tidak adekuat pada pasien dengan FA pada PPOK. Terdapatnya PPOK pada FA merupakan penyebab semua kematian selama pengamatan 1 tahun, penyebab kematian kardiovaskular tetapi bukan faktor risiko untuk stroke. ${ }^{36}$

Penelitian Shi dkk pada 70 pasien PPOK eksaserbasi yang dibagi menjadi dua kelompok yang mendapatkan antikoagulan dan kontrol didapatkan hasil yakni terapi konvensional dengan low molecular weight (LMW) heparin dapat meningkatkan status koagulasi pada PPOK eksaserbasi, mengurangi kekentalan darah, meningkatkan fungsi kardiopulmoner dan mengurangi komplikasi. Oleh karena itu low molecular weight heparin dapat digunakan pada PPOK eksaserbasi. Aktivitias koagulasi pada pasien PPOK eksaserbasi secara signifikan didapatkan peningkatan kadar D-Dimer dan fibrinogen. ${ }^{37}$

\section{Tatalaksana Fibrilasi Atrium Pada PPOK}

Pada prinsipnya tatalaksana fibrilasi atrium terdiri dari 3 komponen yaitu kontrol irama jantung/rhythm control, kontrol laju jantung/rate control dan menurunkan risiko tromboemboli dengan pemberian antikoagulan. Rekomendasi yang telah ditetapkan oleh European Society of Cardiology (ESC) tahun 2010 mengenai AF pada penyakit paru adalah sebagai berikut: ${ }^{15}$

Kelas I.

1. Koreksi hipoksemia dan asidosis direkomendasikan sebagai terapi primer pada pasien yang mengalami AF saat eksaserbasi penyakit paru kronik.

2. Kardioversi elektrik harus dicoba dilakukan pada pasien dengan penyakit paru yang mengalami hemodinamik tidak stabil sebagai akibat AF.

Kelas II

1. Antagonis kanal kalsium nondihidropiridin (diltiazem atau verapamil) direkomendasikan untuk mengontrol irama ventrikel pada pasien dengan penyakit paru obstruktif.

2. Penghambat beta-1 selektif (misal, bisoprolol) pada dosis kecil sebaiknya dipertimbangkan sebagai pilihan obat untuk mengendalikan laju jantung.

\section{Kelas III}

1. Teofilin dan agonis beta tidak direkomendasikan pada pasien penyakit paru bronkospastik yang mengalami AF.

2. Penyekat beta yang tidak selektif, sotalol, propafenon dan adenosin tidak direkomendasikan pada penyakit paru obstruktif yang mengalami AF.

\section{Kesimpulan}

1. Komplikasi kardiovaskular tersering yang terdapat pada PPOK adalah aritmia jantung dalam hal ini adalah fibrilasi atrium.

2. Patofisiologi fibrilasi atrium pada PPOK adalah akibat faktor atrium, inflamasi, aktivasi RAAS, penyakit jantung koroner, gangguan tonus otonom dan farmakologis.

3. Komplikasi yang dapat ditimbulkan dari fibrilasi atrium adalah tromboemboli sistemik. Sistem skoring $\mathrm{CHA}_{2} \mathrm{DS}_{2}$ VASc merupakan perhitungan risiko stroke pada fibrilasi atrium, terdapat kelompok pasien dengan karakteristik tertentu untuk mengalami kejadian tromboemboli.

4. Pada prinsipnya tatalaksana fibrilasi atrium pada PPOK terdiri dari 3 komponen yaitu kontrol irama jantung/rhythm control, kontrol laju jantung/rate control dan menurunkan risiko tromboemboli dengan pemberian antikoagulan.

5. Salah satu tatalaksana fibrilasi atrium pada PPOK adalah koreksi hipoksemia dan asidosis direkomendasikan sebagai terapi primer terutama pada PPOK eksaserbasi.

\section{Daftar Pustaka}

1. Hurd Suzanne, Buist SA, Rabe KF, Arizueto A, Barnes PJ, Fukuchi $Y$, et al. Global strategy for the diagnosis, management and prevention of chronic obstructive pulmonary disease. Am J Respir Crit Care Med. 2007;176:532-55.

2. World Health Organization. World health report. Available at: http:// www.who.int/respiratory/copd/en/, Accessed on April 9, 2015. 
3. Global Initiative for Chronic Obstructive Lung Disease. Global strategy for the diagnosis, management and prevention of chronic obstructive pulmonary disease update 2015;2-50

4. Yunus F, Wiyono HW, Antariksa B, Kusumo DK, Djajalaksana S, Riyadi J, dkk. Definisi. Di: Antariksa B, Djajalaksana S, Yunus F, Kusumo DK, Wiyono HW, eds.i Penyakit Paru Obstruktif Kronik (PPOK). Jakarta Perhimpunan Dokter Paru Indonesia 2011.h.1-2,55.

5. Global Initiative for Chronic Obstructive Lung Disease. Global strategy for the diagnosis, management and prevention of chronic obstructive pulmonary disease update 2014; 48-49

6. Shujaat A, Minkin R, Eden E. Pulmonary hypertension and chronic cor pulmonale in COPD. International Journal of COPD 2007:2(3)272-282.

7. Buch P, Friberg J, Scharling, Lange P, Prescott E. Reduced lung function and risk of atrial fibrillation in the Copenhagen City Heart Study. Eur Respir J 2003; 21:1012-6.

8. Sin DD, Anthonisen NR, Soriano JB, Agusti AG. Mortality in COPD: role of comorbidities. Eur Respir J 2006; 28:124557.

9. Bestall JC, Paul EA, Garrod R, Gamham R, Jones PW, Wedzicha JA. Usefullness of the Medical Research Council (MRC) dyspnoea scale such as a measure of disability in patients with chronic obstructive pulmonary disease. Thorax 1999;54:581-6

10. Laratta CR, van Eeden S. Acute exacerbation of chronic obstructive pulmonary disease: cardiovascular links. BioMed research international. 2014;2014:528789

11. Jones PW, Harding G, Berry P, Wiklund I, Chen WH, Leidy NK. Development and first validation of the COPD assessment test. Eur Respir J 2009;34:648-54.

12. Zoni-Berisso M, Lercari F, Carazza T, Domenicucci S. Epidemiology of atrial fibrillation: European perspective. Clinical epidemiology. 2014;6:213-20.

13. Fuster V, Ryden LE, Cannom DS, Crijns HJ, Curtis AB, Ellenbogen KA, et al. Guidelines for the management of patients with atrial fibrillation. ACC/AHA/ESC 2006.

14. January CT, Alpert JS, Cigarroa JE, Conti JB, Ezekowitz MD, Field ME, et al. Guidelines for the management of patirnts with atrial fibrilation. AHA/ACC/HRS 2014.

15. European Heart Rhythm A, European Association for CardioThoracic S, Camm AJ, Kirchhof P, Lip GY, Schotten U, et al. Guidelines for the management of atrial fibrillation: the Task Force for the Management of Atrial Fibrillation of the European Society of Cardiology (ESC). European heart journal. 2010;31(19):2369-2429.

16. Gutierrez C, Blanchard DG. Atrial fibrillation : diagnosis and treatment. Am Fam Physician.2011;83(1):61-68.

17. Shih H, Webb CR, Conway WA. Frequency and significance of cardiac arrhythmias in chronic obstructive lung disease. Chest
1988; 94:44-8.

18. Yildiz P, Tukek T, Akkaya V, Sozen AB, Yildiz A, Korkut $F$, et al. Ventricular arrhythmias in patients with COPD are associated with QT dispersion. Chest 2002; 122:2055-61.

19. Asad N, Johnson VMP, Spodick DH. Acute right atrial strain: regression in normal as well as abnormal p-wave amplitudes with treatment of obstructive pulmonary disease. Chest 2003; 124:560-4.

20. Schena M, Clini E, Errera D, Quadri A. Echo-doppler evaluation of left ventricular impairment in chronic cor pulmonale. Chest 1996; 109:1146-51.

21. Guo Y, Lip GYH, Apostolakis S. Inflammation in atrial fibrillation. Journal of the American Collage of Cardiology 2012;60:2263-70.

22. Andreas S, Anker SD, Scanlon PD, Somers VK. Neurohumoral activation as a link to systemic manifestations of chronic lung disease. Chest 2005; 128:3618-24.

23. Anand IS, Chandrashekhar, Ferrari R, Srama R, Guleria R, Jindal $\mathrm{SK}$, et al. Pathogenesis of congestive state in chronic obstructive pulmonary disease. Circulation 1992; 86:12-21.

24. Sin DD, Man SFP. Why are patients with chronic obstructive pulmonary disease at increased risk of cardiovascular disease? Circulation 2003; 107:1514-9.

25. Stein PK, Nelson P, Rottman JN, Howard D, Ward SM, Kleiger RE, et al. Heart rate variability reflects severity of COPD in PiZ $\alpha 1$-antitripsin deficiency. Chest 1998; 113:327-33.

26. Incalzi RA, Pistelli R, Fuso L, Cocchi A, Bonnetti MG, Giordano A. Cardiac arrhythmias and left ventricular function in respiratory failure from chronic obstructive pulmonary disease. Chest 1990; 97:1092-7.

27. Mehra R, Benjamin EJ, Shahar E, Gottlieb DJ, Nawabit R, Kirchner HL, et al. Association of nocturnal arrhythmias with sleep-disordered breathing: The Sleep Heart Health Study. American journal of respiratory and critical care medicine. 2006;173(8):910-6.

28. Shibata Y, Watanabe T, Osaka D, Abe S, Inoue S, Tokairin $\mathrm{Y}$, et al. Impairment of pulmonary function is an independent risk factor for atrial fibrillation: the Takahata study. International journal of medical sciences. 2011;8(7):514-22.

29. Van der Hooft CS, Heeringa J, Brusselle GG, Hofman A, Witteman JCM, Kingma JH, et al. Corticosteroids and the risk of atrial fibrillation. Arch Intern Med 2006; 166:1016-29.

30. Huerta C, Lanes SF, Garcia Rodriguez LA. Respiratory medications and the risk of cardiac arrhythmias. Epidemiology. 2005;16:360-366.

31. Salpenter SR, Ormiston TM, Salpenter EE. Cardiovascular effects of $\beta$ - agonists in patients with asthma and COPD: a meta analysis. Chest 2004; 125:2309-21.

32. Loukeri AA, Kampolis CF, Taksis I, Loukeri PSN, Tzagaraki A, Kythreotis P. Inhaled beta- 2 agonist and beta blokers in patients 
with chronic obstructive pulmonary disease and cardiovascular comorbidities: therapeutic dilemmas, myths and realities. Pneumon 2013, 26(1):59-74.

33. Pisters R, Lane DA, Nieuwlaat R, de Vos CB, Crijns HJ, Lip GY. A novel user-friendly score (HAS-BLED) to assess 1-year risk of major bleeding in patients with atrial fibrillation: the Euro Heart Survey. Chest. 2010;138(5):1093-100.

34. Eikelboom JW, Weitz JI. Update on antithrombotic therapy; new anticoagulants. Circulation.2010;121:1523-1532.

35. Camm AJ, Lip GYH, Caterina RD, Savelieva I, Atar D, Hohnloser SH, et.al. Focused update of the ESC Guidelines for the management of atrial fibrillation. European Heart Journal.2012 (33): 2719-2747.

36. Huang B, Yang Y, Liang Y, Zhang H, Tian L, Shao X, et. al. Clinical charactersitics and prognostic significance of chronic obstructive pulmonary disease in patients with atrial fibrillation: result from a multicenter atrial fibrillation registry study. Journal Am Med Dir Assoc.2013;15(8):576-81.

37. Shi X, Li H. Anticoagulation therapy in patients with chronic obstructive pulmonary disease in the acute exacerbation stage. Experimental and therapeutic medicine. 2013 (5): 13671370. 